\title{
Cleanliness of Ti-bearing Al-killed ultra-low-carbon steel during different heating processes
}

\author{
Jian-long Guo, Yan-ping Bao, and Min Wang \\ State Key Laboratory of Advanced Metallurgy, University of Science and Technology Beijing, Beijing 100083, China \\ (Received: 18 April 2017; revised: 11 July 2017; accepted: 16 July 2017)
}

\begin{abstract}
During the production of Ti-bearing Al-killed ultra-low-carbon (ULC) steel, two different heating processes were used when the converter tapping temperature or the molten steel temperature in the Ruhrstahl-Heraeus (RH) process was low: heating by Al addition during the RH decarburization process and final deoxidation at the end of the RH decarburization process (process-I), and increasing the oxygen content at the end of RH decarburization, heating and final deoxidation by one-time $\mathrm{Al}$ addition (process-II). Temperature increases of $10^{\circ} \mathrm{C}$ by different processes were studied; the results showed that the two heating processes could achieve the same heating effect. The T.[O] content in the slab and the refining process was better controlled by process-I than by process-II. Statistical analysis of inclusions showed that the numbers of inclusions in the slab obtained by process-I were substantially less than those in the slab obtained by process-II. For process-I, the $\mathrm{Al}_{2} \mathrm{O}_{3}$ inclusions produced by $\mathrm{Al}$ added to induce heating were substantially removed at the end of decarburization. The amounts of inclusions were substantially greater for process-II than for process-I at different refining stages because of the higher dissolved oxygen concentration in process-II. Industrial test results showed that process-I was more beneficial for improving the cleanliness of molten steel.
\end{abstract}

Keywords: low carbon steel; cleanliness; RH process; heating; inclusions

\section{Introduction}

Ti-bearing Al-killed ultra-low-carbon (ULC) steel is often used for home appliances and automobiles and has very high cleanliness and surface quality requirements of the slab. Large nonmetallic inclusions in steel are the main source of defects in cold-rolled steel plates [1-5]. The main process for producing Ti-bearing Al-killed ULC steel is basic oxygen furnace $(\mathrm{BOF}) \rightarrow$ Ruhrstahl-Heraeus $(\mathrm{RH})$ reactor $\rightarrow$ continuous casting (CC). If the converter tapping temperature or the molten steel temperature during the $\mathrm{RH}$ process is low, the temperature should be increased via the reaction of $\mathrm{Al}$ and oxygen in the process to ensure that the casting temperature is reached [6]; however, this process will lead to the generation of a large number of $\mathrm{Al}_{2} \mathrm{O}_{3}$ inclusions and affect the cleanliness of steel. The $\mathrm{Al}_{2} \mathrm{O}_{3}$ and $\mathrm{Al}-\mathrm{O}-\mathrm{Ti}$ inclusions generated during the production of ULC steel lead to serious nozzle clogging [7].

Numerous studies on the cleanliness of ULC steel have been reported. Zhang and $\mathrm{Li}$ [8] studied the influence of Ti on the cleanliness of ULC steel. Other researchers have reported that lower slag oxidizability is beneficial for improving the cleanliness of molten steel during the refining process [9-11]. Wang et al. [12] reported that coordinated control of carbon and oxygen was also beneficial for improving the cleanliness of ULC steel. However, the effect of chemical heating by $\mathrm{Al}$ addition, the timing of $\mathrm{Al}$ addition on the cleanliness of ULC steel, and the inclusion removal mechanism by $\mathrm{Al}$ addition before and after decarburization have not been reported. Through investigation, chemical heating has been found to account for $27.8 \%$ of ULC steel production in some steel plants. In the present work, to study the influence of different heating processes on the cleanliness of ULC steel and to determine the appropriate chemical heating process, we tracked, sampled, and analyzed the total oxygen content (T.[O]); the size, quantity, distribution, and composition of non-metallic inclusions; and the slag content during the whole smelting process. 


\section{Experimental}

\subsection{Production process and steel composition}

The experiment was carried out in a 300-t RH reactor. The production process was as follows: Kanbara reactor $(\mathrm{KR}) \rightarrow \mathrm{BOF} \rightarrow \mathrm{RH}$ reactor $\rightarrow \mathrm{CC}$. The composition of the experimental steel is listed in Table 1.

Industrial experiments involved different heating processes. Process-I was heating by $\mathrm{Al}$ addition during the
$\mathrm{RH}$ decarburization process and final deoxidation at the end of RH decarburization. When using process-I, to reduce the influence of $\mathrm{Al}$ addition on the decarburization rate, the time of $\mathrm{Al}$ addition was controlled at $6 \mathrm{~min}$ after the vacuum started. Process-II was increasing the oxygen content at the end of RH decarburization followed by heating and final deoxidation by one-time $\mathrm{Al}$ addition. To ensure the consistency of the experimental results, the heating temperature was $10^{\circ} \mathrm{C}$ for both processes.

Table 1. Composition of the experimental steel

\begin{tabular}{cccccccc}
\hline $\mathrm{C}$ & $\mathrm{Si}$ & $\mathrm{Mn}$ & $\mathrm{P}$ & $\mathrm{S}$ & $\mathrm{Al}$ & $\mathrm{Ti}$ & $\mathrm{N}$ \\
\hline$\leq 0.0035$ & $\leq 0.03$ & $0.08-0.15$ & $\leq 0.015$ & $\leq 0.012$ & $0.030-0.055$ & $0.050-0.070$ & $\leq 0.004$ \\
\hline
\end{tabular}

\subsection{Sampling and analysis}

In the two different heating processes, steel and slag samples were extracted during the $\mathrm{RH}$ refining process. Steel and slag samples were collected by pail samplers with an inner diameter of $80 \mathrm{~mm}$. The steel sampling position was located $200 \mathrm{~mm}$ below the slag surface. Fig. 1 shows an illustration of the alloy addition and sampling processes during the $\mathrm{RH}$ refining stage, where the time at which vacuum starts is assumed as $0 \mathrm{~min}$.

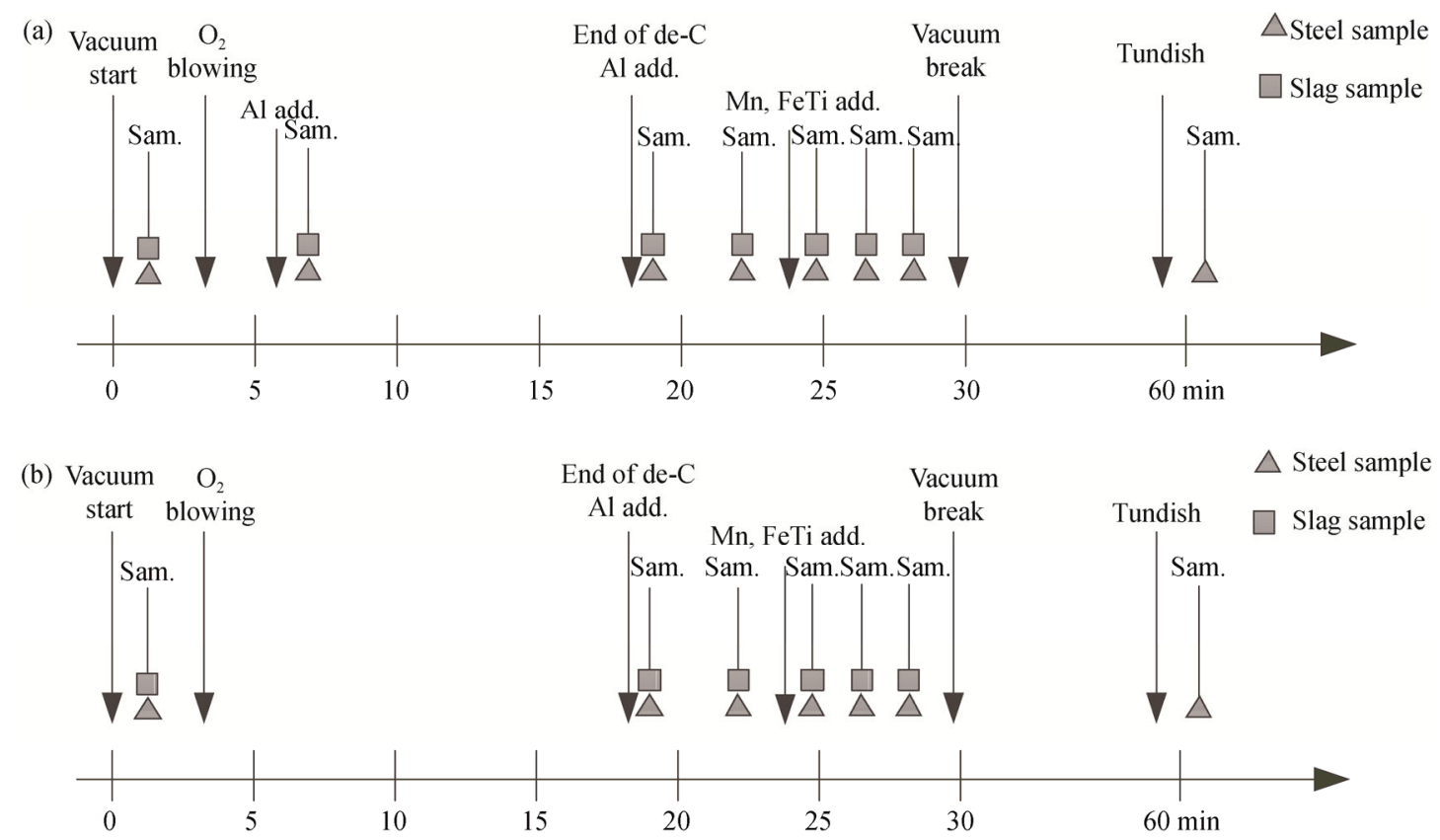

Fig. 1. Illustration of the alloy addition (add.) and sampling (sam.) processes during the RH refining process: (a) process-I; (b) process-II.

The slab was sampled at the edges, one-fourth the distance from the center to the edge in the width direction, and the center of the slab to analyze the inclusions. The T.[O] of the steel samples was analyzed using an EMGA-830 oxygen-nitrogen analyzer. The content of the slag samples was analyzed using an EDX800 X-ray fluorescence spectrometer. Inclusions on the cross-section of the steel samples were characterized using an Oxford-Inca automatic inclusion analysis system; the composition, size, and distribution of the inclusions were measured. To ensure the accuracy and consistency of the scanning data, the scanning area was $7 \mathrm{~mm} \times 7 \mathrm{~mm}$. The morphology of inclusions was analyzed by scanning electron microscopy-energydispersive X-ray spectroscopy (SEM-EDS).

\section{Results}

\subsection{Temperature evolution of the refining process}

Fig. 2 shows the temperature evolution during the ULC 
steel refining process; the tapping temperature for the heating processes was $10^{\circ} \mathrm{C}$ lower than that for the normal process. At $6 \mathrm{~min}$ after vacuum started, $88 \mathrm{~kg}$ of $\mathrm{Al}$ was added to induce heating for process-I. For the normal process and process-I, the temperature at the end of decarburization was controlled at $1590^{\circ} \mathrm{C}$. When the vacuum was broken, the temperatures of the molten steel for process-I and process-II were controlled at 1586 and $1587^{\circ} \mathrm{C}$, indicating that two processes achieved the same heating effect.

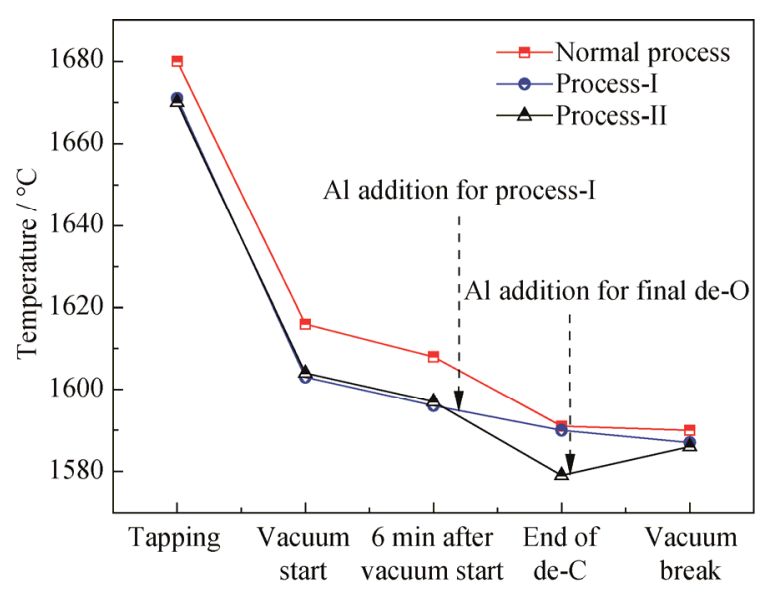

Fig. 2. Temperature evolution of the refining process.

\subsection{T. $[\mathrm{O}]$ evolution of the refining process}

Fig. 3 shows the T.[O] evolution for all of the processes at different refining stages: the end of $\mathrm{RH}$ decarburization, 6 min after deoxidation by $\mathrm{Al}$ addition, 4 min after alloy addition, vacuum break, and in the tundish. The T.[O] content at the end of $\mathrm{RH}$ decarburization is an important factor affecting the cleanliness of ULC steel [13]. In process-I, the T.[O] content at the end of $\mathrm{RH}$ decarburization was $400 \mathrm{ppm}$, whereas the T.[O] content at the end of RH decarburization was $480 \mathrm{ppm}$ in process-II, which is substantially greater than that in process-I. The T.[O] in the molten steel was effectively removed after the $\mathrm{RH}$ cycle treatment and sedation. The T.[O] in the tundish is another important factor affecting the cleanliness of ULC steel [2]. For process-II, the T.[O] in the tundish reached $56 \mathrm{ppm}$, which is twice as high as that for the normal process and $70 \%$ up compared with process-I. Therefore, process-I can control the T.[O] during the refining process more effectively than process-II and can improve the cleanliness of the ULC steel.

\subsection{T. $[O]$ in slab}

The cleanliness of the steel can be measured on the basis of the T.[O] in the slab. The T.[O] content in the slab by different heating processes is shown in Fig. 4. To avoid the in- fluence of sampling positions, the T.[O] values at the edge, one-fourth the distance from the center to the edge, and at the center in the slab were compared.

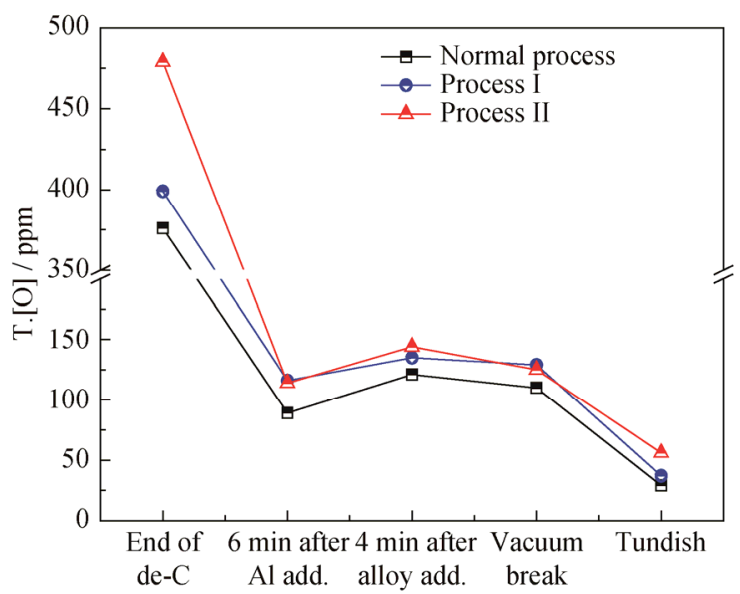

Fig. 3. Evolution of $\mathrm{T} .[\mathrm{O}]$ during the refining process.

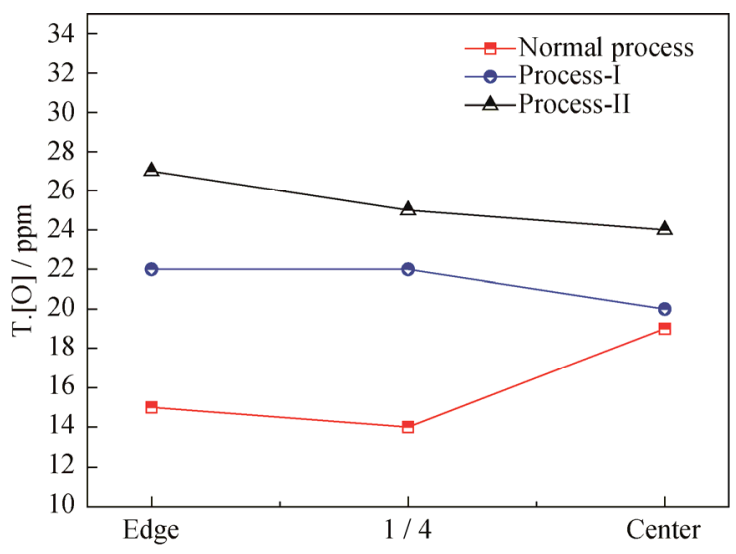

Fig. 4. T. $[\mathrm{O}]$ in the slab by different heating processes.

As shown in Fig. 4, the T.[O] contents in the slab from the edge to the center were 15,14 , and $19 \mathrm{ppm}$ in the case of the normal process; these values are lower than the T.[O] contents in the case of the heating processes. A comparison of the two different heating processes reveals that the T.[O] in the slab produced by process-I was approximately 22 ppm, whereas that in the slab produced by process-II was approximately $26 \mathrm{ppm}$. Thus, the T.[O] in the slab produced by process-I was lower than that in the slab produced by process-II.

\subsection{Evolution of slag composition at different refining stages}

In ULC steel, the inclusions are mainly $\mathrm{Al}_{2} \mathrm{O}_{3}$. Therefore, the slag composition should be controlled to remove $\mathrm{Al}_{2} \mathrm{O}_{3}$ inclusions from the steel. The $\mathrm{C} / \mathrm{A}\left(w \mathrm{CaO} / w \mathrm{Al}_{2} \mathrm{O}_{3}\right)$ ratio and $(\mathrm{FeO}+\mathrm{MnO})$ content are general parameters that represent 
the oxidizing tendency of a slag [14-16]. To ensure that $\mathrm{Al}_{2} \mathrm{O}_{3}$ inclusions could be removed effectively, the $\mathrm{C} / \mathrm{A}$ ratio in the slag was controlled between 1.2 and 2.0, and the $(\mathrm{FeO}$ $+\mathrm{MnO}$ ) content was controlled below $10 \mathrm{wt} \%$. The slag contents at different refining stages in different processes are listed in Table 2. When vacuum started, the C/A ratio in the slag was maintained between 1.5 and 1.7 through the slag modification process and the contents of the slag of three test heats were similar. This result indicates that the oxidiza- bility of molten steel in slag and the inclusion adsorption capacity of slag were similar in all processes. The $\mathrm{Al}_{2} \mathrm{O}_{3}$ content in the slag increased gradually with the extension of the pure degassing time, which indicates that the inclusions in molten steel were continuously floating to the top slag during the RH treatment process. In all processes, the $(\mathrm{FeO}$ $+\mathrm{MnO}$ ) content generally decreased from the end of decarburization to vacuum break and the content was controlled below $8 \mathrm{wt} \%$.

Table 2. Slag composition at different refining stages in different processes

\begin{tabular}{|c|c|c|c|c|c|c|c|}
\hline Process & Description & $\mathrm{CaO}$ & $\mathrm{Al}_{2} \mathrm{O}_{3}$ & $\mathrm{SiO}_{2}$ & $\mathrm{MgO}$ & $\mathrm{FeO}$ & $\mathrm{MnO}$ \\
\hline \multirow{5}{*}{ Normal process } & Vacuum start & 49.5 & 29.6 & 7.2 & 5.9 & 6.2 & 1.6 \\
\hline & End of de-C & 49.8 & 28.6 & 7.9 & 6.1 & 5.8 & 1.9 \\
\hline & 4 min after $\mathrm{Al}$ addition & 49.7 & 29.3 & 7.4 & 6.4 & 4.9 & 2.3 \\
\hline & 4 min after Ti addition & 49.2 & 31.7 & 7.1 & 5.3 & 5.3 & 1.4 \\
\hline & Vacuum break & 48.3 & 32.2 & 6.6 & 6.3 & 5.1 & 1.5 \\
\hline \multirow{5}{*}{ Process-I } & Vacuum start & 49.6 & 29.9 & 7.9 & 5.5 & 5.7 & 1.4 \\
\hline & End of de-C & 48.7 & 31.6 & 6.4 & 6.1 & 5.3 & 1.9 \\
\hline & 4 min after $\mathrm{Al}$ addition & 48.3 & 33.2 & 6.0 & 5.7 & 5.6 & 1.2 \\
\hline & 4 min after Ti addition & 47.7 & 34.7 & 5.7 & 5.9 & 4.9 & 1.1 \\
\hline & Vacuum break & 47.9 & 35.5 & 6.0 & 5.5 & 4.6 & 0.7 \\
\hline \multirow{5}{*}{ Process-II } & Vacuum start & 50.1 & 29.3 & 7.2 & 6.6 & 5.1 & 1.7 \\
\hline & End of de-C & 49.7 & 29.5 & 6.6 & 7.3 & 5.0 & 1.9 \\
\hline & 4 min after $\mathrm{Al}$ addition & 48.9 & 30.3 & 7.6 & 5.9 & 5.2 & 1.5 \\
\hline & 4 min after Ti addition & 46.3 & 33.4 & 6.3 & 7.7 & 4.9 & 1.5 \\
\hline & Vacuum break & 47.8 & 33.8 & 5.8 & 6.9 & 3.9 & 1.8 \\
\hline
\end{tabular}

\subsection{Inclusion size and number density distribution}

The distribution of inclusions was analyzed using the Oxford-Inca inclusion analysis system; the analysis position was one-fourth the distance from the edge to the center of the slab. The results are shown in Fig. 5, where each color represents a characteristic inclusion.

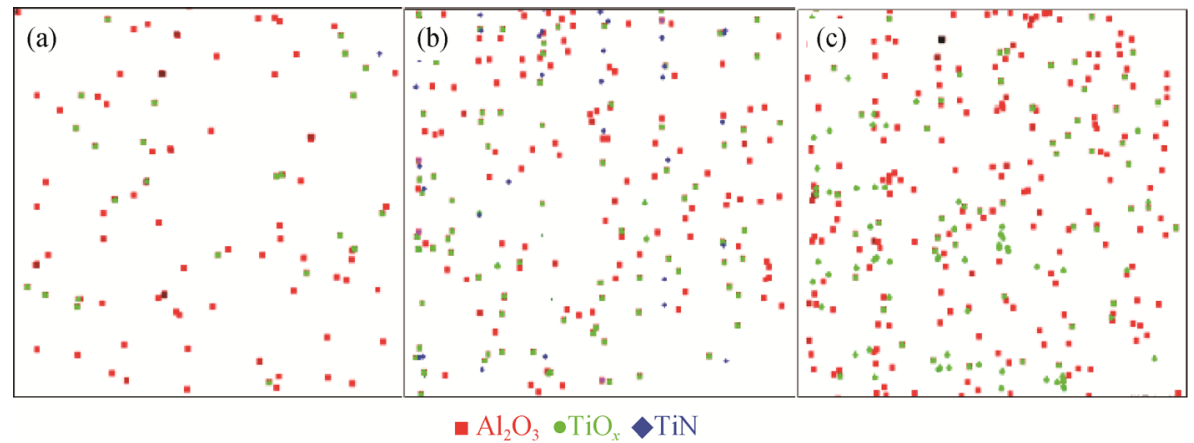

Fig. 5. Distribution of inclusions in slabs subjected to different heating processes: (a) normal process; (b) process-I; (c) process-II.

Fig. 5 shows that the inclusions were mainly $\mathrm{Al}_{2} \mathrm{O}_{3}$, $\mathrm{Al}_{2} \mathrm{O}_{3}-\mathrm{TiO}_{x}, \mathrm{TiN}$, and their complex inclusions; it also shows that the distribution of inclusions in the slab of
process-II was substantially greater than those of process-I and the normal process. The number distribution of $\mathrm{Al}_{2} \mathrm{O}_{3}$ and $\mathrm{Al}_{2} \mathrm{O}_{3}-\mathrm{TiO}_{x}$ inclusions in different sizes is shown in Figs. 
6 and 7. The numbers of $\mathrm{Al}_{2} \mathrm{O}_{3}$ and $\mathrm{Al}_{2} \mathrm{O}_{3}-\mathrm{TiO}_{x}$ inclusions in the slab for the normal process were 118 , including $92 \mathrm{Al}_{2} \mathrm{O}_{3}$ inclusions and $26 \mathrm{Al}_{2} \mathrm{O}_{3}-\mathrm{TiO}_{x}$ inclusions; by contrast, they were 156 in process-I, including $118 \mathrm{Al}_{2} \mathrm{O}_{3}$ inclusions and $38 \mathrm{Al}_{2} \mathrm{O}_{3}-\mathrm{TiO}_{x}$ inclusions, and 295 in process-II, including $237 \mathrm{Al}_{2} \mathrm{O}_{3}$ inclusions and $58 \mathrm{Al}_{2} \mathrm{O}_{3}-\mathrm{TiO}_{x}$ inclusions. $\mathrm{A}$ comparison of the two different heating processes and the normal process reveals that process-II resulted in $90 \%$ more inclusions than process-I and $150 \%$ more inclusions than the normal process. $\mathrm{Al}_{2} \mathrm{O}_{3}-\mathrm{TiO}_{x}$ inclusions can cause serious nozzle clogging [7]. Process-II resulted in 50\% more $\mathrm{Al}_{2} \mathrm{O}_{3}-\mathrm{TiO}_{x}$ inclusions than process- $\mathrm{I}$ and $120 \%$ more than the normal process. Process-II resulted in greater numbers of $\mathrm{Al}_{2} \mathrm{O}_{3}$ and $\mathrm{Al}_{2} \mathrm{O}_{3}-\mathrm{TiO}_{x}$ inclusions larger than $4 \mu \mathrm{m}$ than process-I and the normal process. Thus, considering the type, quantity, distribution, and size of the inclusions, the cleanliness of the slab obtained by process-I is better than that obtained by process-II.

\section{Discussion}

Before deoxidation, a large number of spherical or ellipsoidal (Fe,Mn)O particles are dispersed in the molten steel matrix, as shown in Fig. 8. The single-particle diameter is 1-3 $\mu \mathrm{m}$, and a few particles gather together to form clusters.

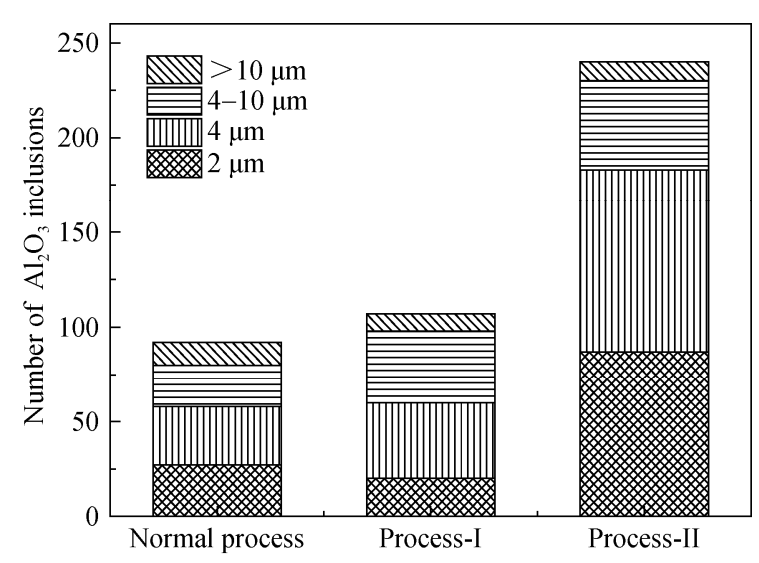

Fig. 6. Size distribution of $\mathrm{Al}_{2} \mathrm{O}_{3}$ inclusions in the slabs.

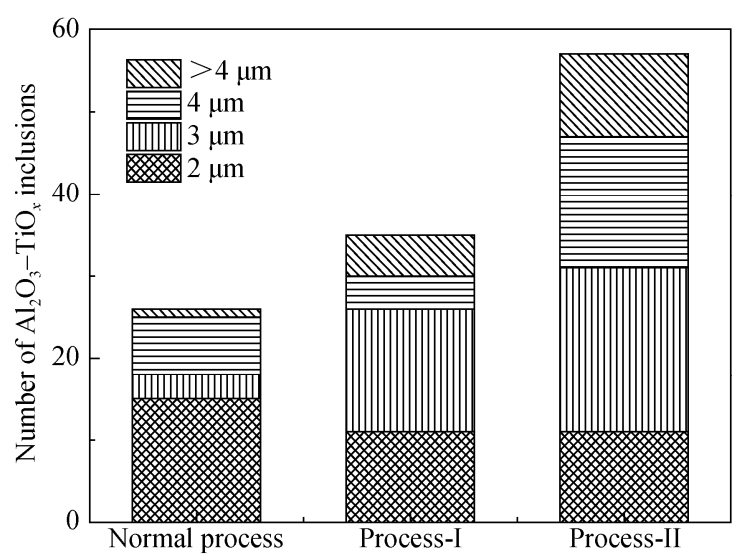

Fig. 7. Size distribution of $\mathrm{Al}_{2} \mathrm{O}_{3}-\mathrm{TiO}_{x}$ inclusions in the slabs.

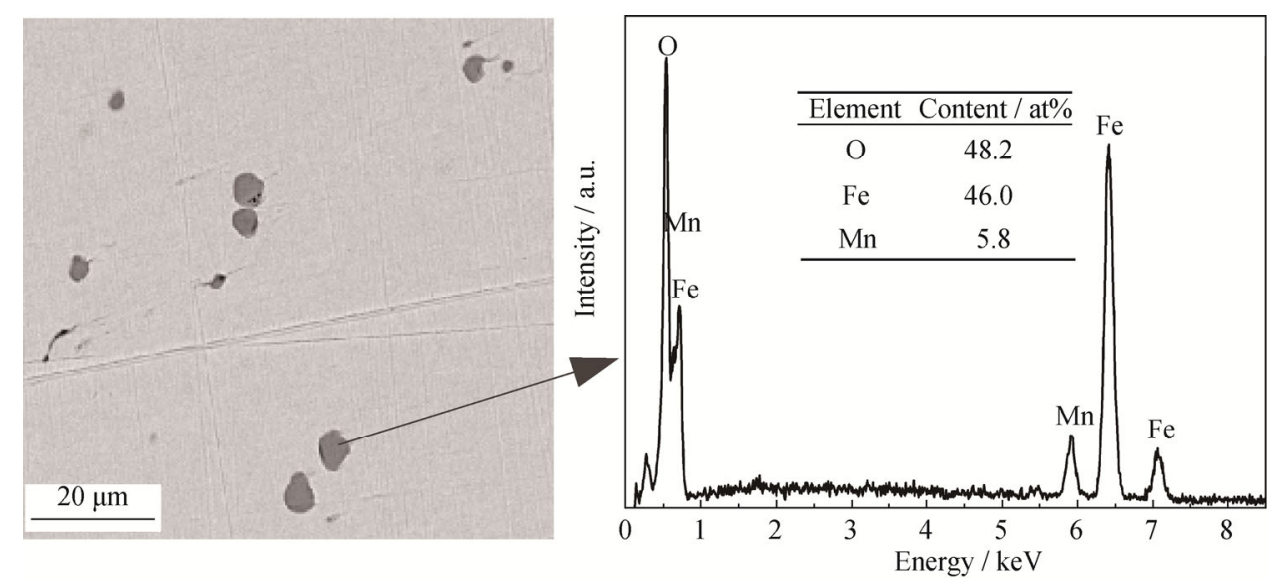

Fig. 8. SEM-EDS results of typical inclusions before deoxidation.

After the addition of $\mathrm{Al},[\mathrm{Al}]$ will react with oxygen, as shown in Eqs. (1) and (2):

$2[\mathrm{Al}]+3[\mathrm{O}] \rightleftharpoons\left(\mathrm{Al}_{2} \mathrm{O}_{3}\right)_{\mathrm{s}}$

$2[\mathrm{Al}]+3[\mathrm{MO}]_{\text {inclusion }} \rightleftharpoons\left(\mathrm{Al}_{2} \mathrm{O}_{3}\right)_{\mathrm{s}}+3[\mathrm{M}]$

In Eq. (2), $\mathrm{M}$ is $\mathrm{Fe}$ or $\mathrm{Mn}$. In the reaction process, the main factor affecting inclusion numbers is the dissolved oxygen concentration before $\mathrm{Al}$ addition. The higher the dissolved oxygen concentration, the greater the Al addition and the greater the inclusion numbers [11]. Metallurgical parameters associated with different test processes are listed in Table 3.

For the normal process, the dissolved oxygen concentration before final deoxidation was $389 \mathrm{ppm}$, which is higher than that in process-I. However, because the total amount of $\mathrm{Al}$ addition for the normal process was lower than that for process-I and process-II, the inclusion numbers for the normal process were lower than those for process-I and process-II, as mentioned in section 3.5. 
Table 3. Metallurgical parameters in different test processes

\begin{tabular}{cccccc}
\hline Process & Mass / $t$ & {$[\mathrm{O}]$ before heating / ppm } & $\begin{array}{c}\text { Amount of heating Al } \\
\text { addition } / \mathrm{kg}\end{array}$ & $\begin{array}{c}\text { [O] before de-O / ppm } \\
\text { Amount of De-O } \\
\mathrm{Al} \mathrm{addition} / \mathrm{kg}\end{array}$ \\
\hline Normal process & 308 & - & - & 389 & 358 \\
Process-I & 311 & 475 & - & 359 & 316 \\
Process-II & 314 & - & - & 423 & 402 \\
\hline
\end{tabular}

In process-I, $\mathrm{Al}$ addition was divided into two parts. Part of the $\mathrm{Al}$ was added during the decarburization process for heating, where the inclusions require a longer time to remove; because the dissolved oxygen in the molten steel was reduced, the inclusions produced by final deoxidation were also reduced accordingly. The distribution of the inclusions at different refining stages for process-I was analyzed. The results corresponding to $2 \mathrm{~min}$ after heating by $\mathrm{Al}$ addition at the end of the $\mathrm{RH}$ decarburization process are shown in Fig. 9(a). At 2 min after heating by $\mathrm{Al}$ addition, the main inclusions were $\mathrm{Al}_{2} \mathrm{O}_{3},(\mathrm{Fe}, \mathrm{Mn}) \mathrm{O}$, and $\mathrm{Al}_{2} \mathrm{O}_{3}$ wrapped in (Fe,Mn)O. The SEM-EDS analysis results for $\mathrm{Al}_{2} \mathrm{O}_{3}$ wrapped in $(\mathrm{Fe}, \mathrm{Mn}) \mathrm{O}$ are shown in Fig. 10. At the end of decarburization, the main inclusions were (Fe,Mn)O and the $\mathrm{Al}_{2} \mathrm{O}_{3}$ inclusions had been substantially removed in the same heat, as shown in Fig. 9(b). The numbers of inclusions at different stages are shown in Fig. 11. The $\mathrm{Al}_{2} \mathrm{O}_{3}$ and $\mathrm{Al}_{2} \mathrm{O}_{3}$ wrapped in ( $\left.\mathrm{Fe}, \mathrm{Mn}\right) \mathrm{O}$ inclusions at 2 min after $\mathrm{Al}$ addition accounted for $96.6 \%$ of the total; however, at the end of decarburization, they accounted for only $14.2 \%$ of the total for process-I. From 2 min after $\mathrm{Al}$ addition to the end of decarburization, the number of (Fe, Mn)O inclusions increased because of the second $\mathrm{O}_{2}$ blowing at 4 min after $\mathrm{Al}$ addition to ensure decarburization. However, the removal rate of $\mathrm{Al}_{2} \mathrm{O}_{3}$ and $\mathrm{Al}_{2} \mathrm{O}_{3}$ wrapped in $(\mathrm{Fe}, \mathrm{Mn}) \mathrm{O}$ inclusions reached $72.3 \%$. Therefore, in the case of process-I, the inclusions of $\mathrm{Al}_{2} \mathrm{O}_{3}$ and $\mathrm{Al}_{2} \mathrm{O}_{3}$ wrapped in (Fe,Mn)O were obviously removed via the molten steel cycle and the main inclusions before deoxidation were similar to those in the normal process.

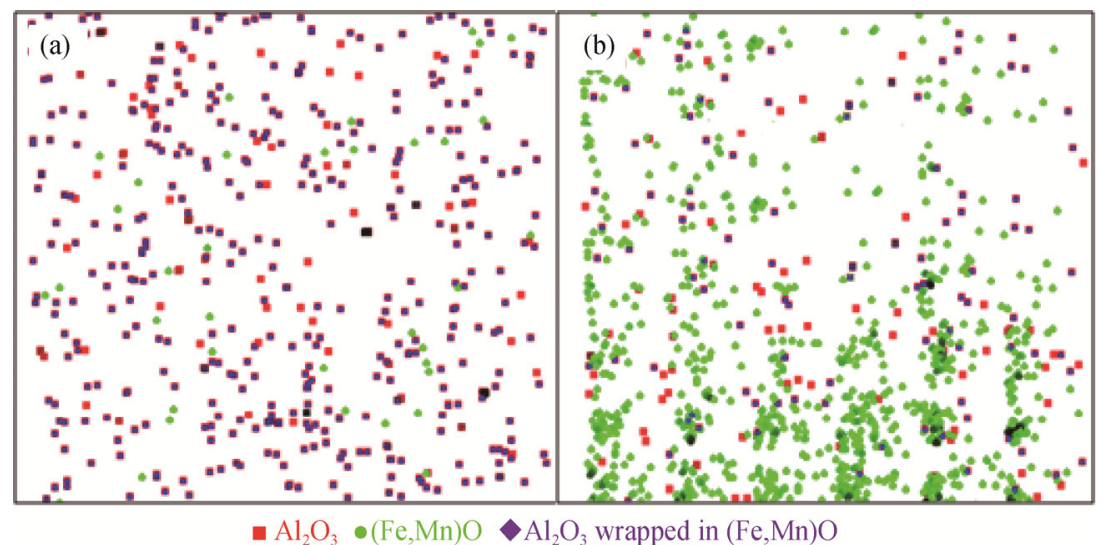

Fig. 9. Distribution of inclusions at different refining stages for process-I: (a) 2 min after heating by Al addition; (b) at the end of RH decarburization.

For process-II, the dissolved oxygen before deoxidation was $423 \mathrm{ppm}$, which was significantly higher than that for process-I and the normal process. The greater dissolved oxygen content in the case of process-II indicates that more $\mathrm{Al}_{2} \mathrm{O}_{3}$ inclusions were generated. Figs. 12 and 13 show the distribution and quantity of inclusions at different refining stages for process-I and process-II: 6 min after Al addition (before Ti addition) and 6 min after Ti addition (vacuum break). The main inclusion type after $\mathrm{Al}$ addition is $\mathrm{Al}_{2} \mathrm{O}_{3}$, and the inclusion numbers at $6 \mathrm{~min}$ after $\mathrm{Al}$ addition for process-I and process-II are 392 and 547, respectively. The main inclusion type after $\mathrm{Ti}$ addition was $\mathrm{Al}_{2} \mathrm{O}_{3}$ and $\mathrm{Al}_{2} \mathrm{O}_{3}-\mathrm{TiO}_{x}$ complex inclusions; the $\mathrm{Al}_{2} \mathrm{O}_{3}$ and $\mathrm{Al}_{2} \mathrm{O}_{3}-\mathrm{TiO}_{x}$ complex inclusion numbers at 6 min after $\mathrm{Ti}$ addition for process-I are 217 and 58, respectively, whereas the $\mathrm{Al}_{2} \mathrm{O}_{3}$ and $\mathrm{Al}_{2} \mathrm{O}_{3}-\mathrm{TiO}_{x}$ complex inclusion numbers for process-II are 395 and 115, respectively. Thus, the inclusion numbers for process-I were substantially lower than those for process-II at different refining stages. Because the treatment time was the same, the oxidizability of molten steel by slag and the inclusion adsorption capacity of slag were similar for process-I and process-II, as mentioned in section 3.4; however, the inclusion numbers in molten steel for process-II were still greater. Therefore, in the case of process-I, inclusions are easier to remove, and cleanliness control is more effective. 


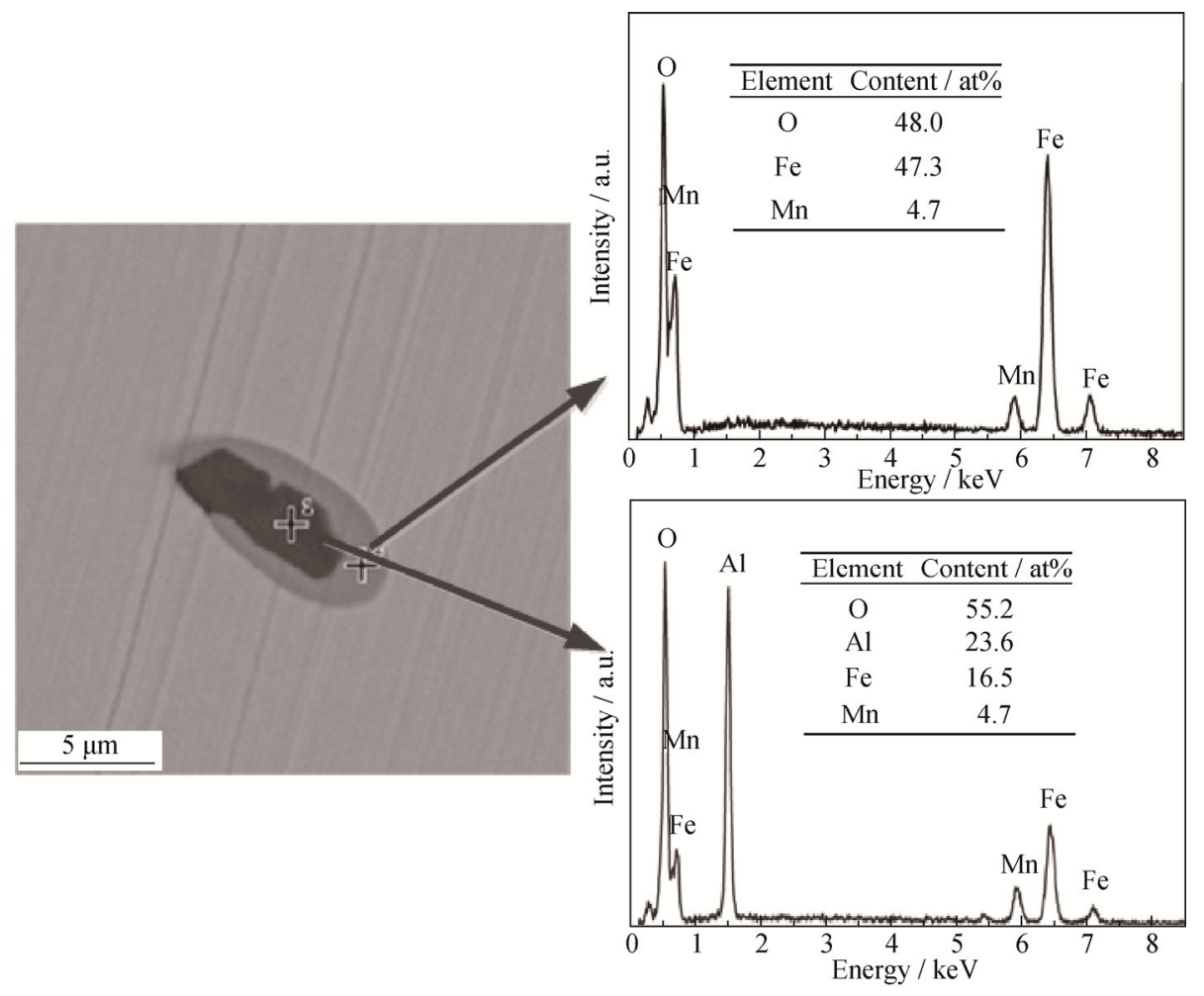

Fig. 10. SEM-EDS analysis results for $\mathrm{Al}_{2} \mathrm{O}_{3}$ wrapped in (Fe,Mn)O after the addition of $\mathrm{Al}$ during the decarburization process.

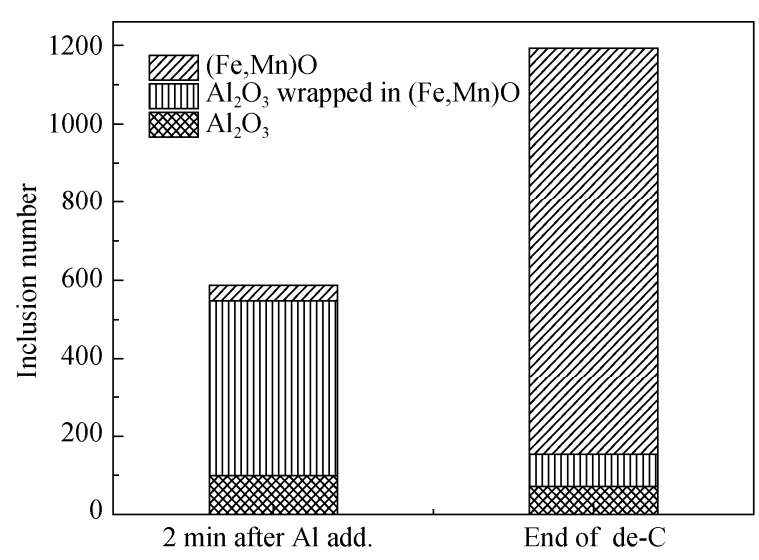

Fig. 11. Quantitative distribution of different inclusions for process-I.

To further verify the effect of heating on the cleanness of different processes, the T.[O] in the slab of 150 heats in industrial production were compared; the results are shown in Fig. 14. The T.[O] in the normal process was lower than that in the heating process; however, the T.[O] could be reduced from 22 to $17 \mathrm{ppm}$ by using process-I compared with using process-II.

\section{Conclusions}

(1) For process-I and process-II, the same heating effect could be achieved.

(2) A comparison of the T.[O] and inclusion numbers of the two heating processes revealed that the T.[O] content in the slab was lower in the case of process-I. Process-II re sulted in greater numbers of $\mathrm{Al}_{2} \mathrm{O}_{3}$ inclusions and $\mathrm{Al}_{2} \mathrm{O}_{3}-\mathrm{TiO}_{x}$ inclusions than process-I and the normal process.

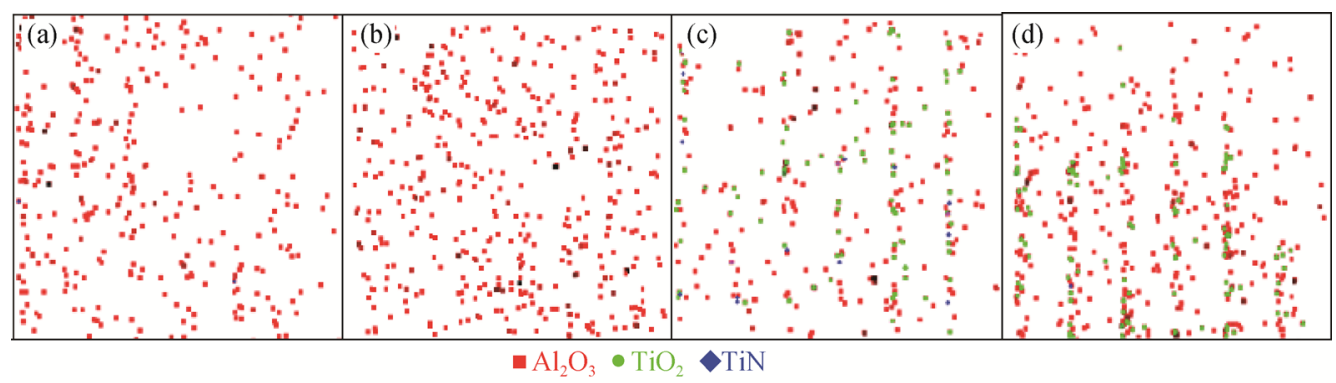

Fig. 12. Distribution of inclusions at different refining stages: (a) 6 min after Al addition for process-I; (b) 6 min after Al addition for process-II; (c) $6 \mathrm{~min}$ after Ti addition for process-I; (d) $6 \mathrm{~min}$ after Ti addition for process-II. 


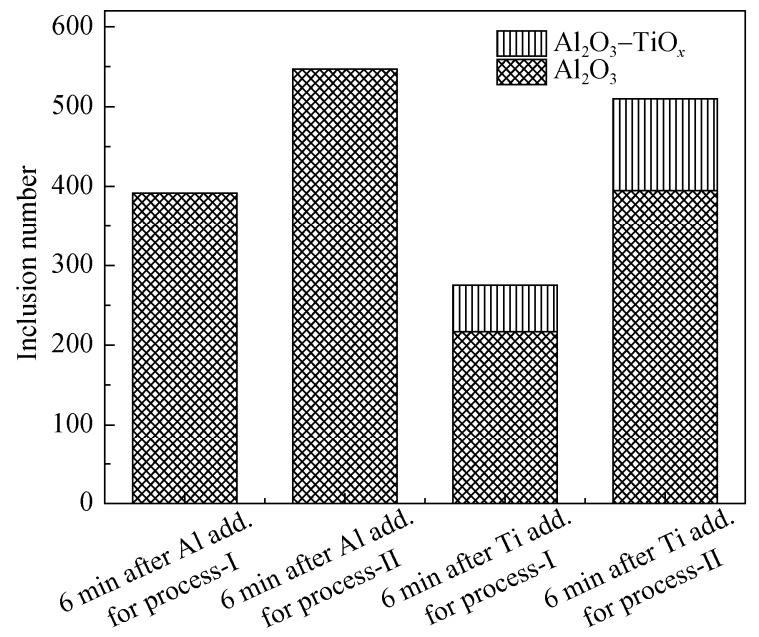

Fig. 13. Quantities of inclusions for process-I and process-II.

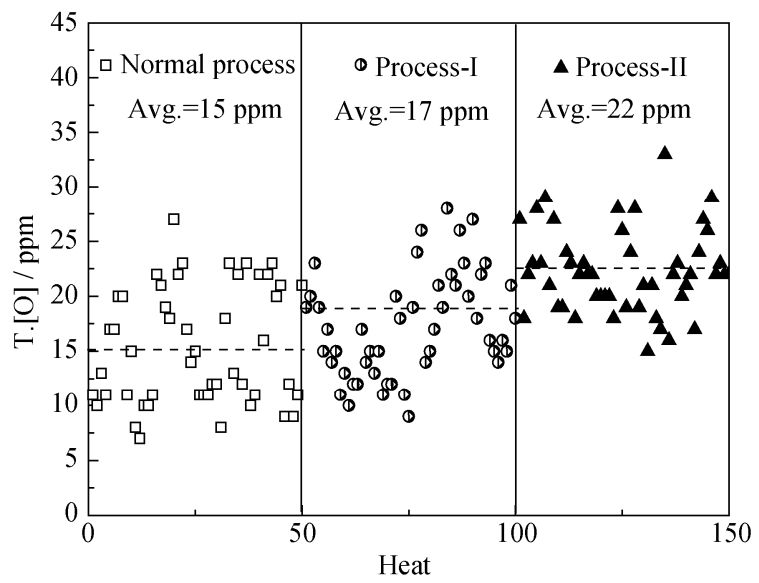

Fig. 14. Comparison of the T.[O] for the normal process, process-I, and process-II.

(3) For the normal process, because the total amounts of Al added were substantially lower than the amounts added during process-I and process-II, the normal process resulted in fewer inclusions. For process-I, inclusions were easier to remove via heating by $\mathrm{Al}$ addition, and the removal rate of $\mathrm{Al}_{2} \mathrm{O}_{3}$ inclusions at the end of decarburization reached $72.3 \%$. For process-II, because the concentration of dissolved oxygen at the end of decarburization was higher than that in process-I, the inclusion numbers were substantially greater than those in process-I at different refining stages.

(4) Industrial production results showed that T.[O] could be reduced from 22 to 17 ppm by using process-I compared with using process-II and that process-I was more beneficial for improving the cleanliness of molten steel.

\section{Acknowledgement}

This work was financially supported by the National Natural Science Foundation of China (No. 51404022).
Open Access This article is distributed under the terms of the Creative Commons Attribution 4.0 International License (http://creativecommons.org/licenses/by/4.0/), which permits unrestricted use, distribution, and reproduction in any medium, provided you give appropriate credit to the original author(s) and the source, provide a link to the Creative Commons license, and indicate if changes were made.

\section{References}

[1] H. Tsunekawa, T. Yamashita, T. Aoyama, and R. Sugihara, Mechanism of formation of streak-shaped defects on ultra-low carbon IF steel for automobile outer panels after press forming and influence of slab reheating temperature before hot rolling and Sb-addition on defects, Tetsu-to-Hagane, 102(2016), No. 4, p. 202.

[2] P. Palai, P.P. Sahoo, A. Dey, T.K. Roy, and V.V. Mahashabde, Constitutional segregation of $\mathrm{Al}_{2} \mathrm{O}_{3}$, in mold slag and its impact on steel cleanliness during continuous casting, Metall. Mater. Trans. B, 44(2013), No. 5, p. 1185.

[3] J.O. Jo, W.Y. Kim, D.S. Kim, and J.J. Pak, Thermodynamics of titanium, nitrogen, and oxygen in liquid alloy steels, Met. Mater. Int., 14(2008), No. 4, p. 531.

[4] Y.M. Qin, X.H. Wang, F.X. Huang, B. Chen, and C.X. Ji, Influence of reoxidation by slag and air on inclusions in IF steel, Metall. Res. Technol., 112(2015), No. 4, art. No. 405.

[5] E. Gutiérrez, S. Garcia-Hernandez, and J.D.J. Barreto, Mathematical analysis of the dynamic effects on the deposition of alumina inclusions inside the upper tundish nozzle, ISIJ Int., 56(2016), No. 8, p. 1394.

[6] P.H. Li, Y.P. Bao, F. Yue, and J. Huang, BOF end-point control of ultra low carbon steel, Iron Steel, 46(2011), No. 10, p. 27.

[7] S. Basu, S.K. Choudhary, and N.U. Girase, Nozzle clogging behaviour of Ti-bearing Al-killed ultra low carbon steel, ISIJ Int., 44(2004), No. 10, p. 1653.

[8] F. Zhang and G.Q. Li, Control of ultra low titanium in ultra low carbon Al-Si killed steel, J. Iron Steel Res. Int., 20(2013), No. 4, p. 20.

[9] Y.M. Qin, X.H. Wang, L.P. Li, and F.X. Huang, Effect of oxidizing slag on cleanliness of IF steel during ladle holding process, Steel Res. Int., 86(2015), No. 9, p. 1037.

[10] C.Y. Liu, F.X. Huang, and X.H. Wang, The effect of refining slag and refractory on inclusion transformation in extra low oxygen steels, Metall. Mater. Trans. B, 47(2016), No. 2, p. 999.

[11] E. Zinngrebe, C.V. Hoek, H. Visser, A. Westendorp, and I.H. Jung, Inclusion population evolution in Ti-alloyed Al-killed 
steel during secondary steelmaking process, ISIJ. Int., 52(2012), No. 1, p. 52

[12] M. Wang, Y.P. Bao, Q. Yang, L.H. Zhao, and L. Lu, Coordinated control of carbon and oxygen for ultra-low-carbon interstitial-free steel in a smelting process, Int. J. Miner. Metall. Mater., 22(2015), No. 12, p. 1252.

[13] W.C. Doo, D.Y. Kim, S.C. Kang, and K.W. Yi, The morphology of $\mathrm{Al}-\mathrm{Ti}-\mathrm{O}$ complex oxide inclusions formed in an ultra low-carbon steel melt during the RH process, Met. Mater. Int., 13(2007), No. 3, p. 249.
[14] W. Yang, X.H. Wang, L.F. Zhang, Q.L. Shan, and X.F. Liu, Cleanliness of low carbon aluminum-killed steels during secondary refining processes, Steel Res. Int., 84(2013), No. 5, p. 473.

[15] B.H. Yoon, K.H. Heo, J.S. Kim, and H.S. Sohn, Improvement of steel cleanliness by controlling slag composition, Ironmaking Steelmaking, 29(2002), No. 3, p. 214.

[16] M.K. Sun, I.H. Jung, and H.G. Lee, Morphology and chemistry of oxide inclusions after $\mathrm{Al}$ and Ti complex deoxidation, Met. Mater. Int., 14(2008), No. 6, p. 791. 